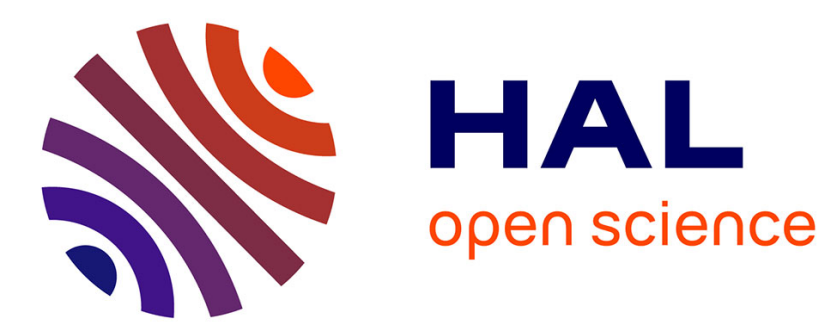

\title{
Trade and empire
}

Kevin H. O'Rourke, Leandro Prados de La Escosura, Guillaume Daudin

\section{To cite this version:}

Kevin H. O'Rourke, Leandro Prados de La Escosura, Guillaume Daudin. Trade and empire. The Cambridge Economic History of Modern Europe, Cambridge University Press (CUP), pp.96-121, 2010, $10.1017 /$ cbo9780511794834.006 . hal-03354873

\section{HAL Id: hal-03354873 https://hal.science/hal-03354873}

Submitted on 26 Sep 2021

HAL is a multi-disciplinary open access archive for the deposit and dissemination of scientific research documents, whether they are published or not. The documents may come from teaching and research institutions in France or abroad, or from public or private research centers.
L'archive ouverte pluridisciplinaire HAL, est destinée au dépôt et à la diffusion de documents scientifiques de niveau recherche, publiés ou non, émanant des établissements d'enseignement et de recherche français ou étrangers, des laboratoires publics ou privés. 
Trade and Empire, 1700-1870

\author{
Kevin H. O'Rourke \\ Trinity College Dublin
}

Leandro Prados de la Escosura

Universidad Carlos III de Madrid

Guillaume Daudin

University of Lille and OFCE 


\title{
Trade and Empire, 1700-1870
}

\begin{abstract}
This paper surveys the rise and fall of the European mercantilist system, and the transition to the modern, well-integrated international economy of the 19th century. It also surveys the literature on the links between trade and economic growth during the period, and on the economic effects of empire.
\end{abstract}

Keywords: trade, empire, history

JEL classification: N43, N73

Kevin H. O'Rourke

Deaprtment of Economics, Trinity College, Dublin 2, Ireland

Tel. 003531896 3594; Fax. 0035316083939

kevin.orourke@tcd.ie

http://www.tcd.ie/Economics/staff/orourkek/homepage.htm

Leandro Prados de la Escosura

Departamento de Historia Económica e Instituciones, Universidad Carlos III de Madrid, Edificio Foronda, Despacho 7.0.14, Calle Madrid, 126, 28903 Getafe (Madrid), Spain Tel. +34 916249623

leandro.prados.delaescosura@uc3m.es

http://www.uc3m.es/uc3m/dpto/HISEC/profesorado/Personal_Leandro_Prados.html

Guillaume Daudin

Département "Économie de la Mondialisation", OFCE and Université Lille-I

69, Quai d'Orsay - 75007 Paris - France

+33(0)144185472

Professor of Economics, Université de Lille and OFCE

gdaudin@mac.com

http://web.mac.com/gdaudin/Guillaume Daudins homepage/Welcome.html 


\section{Introduction. The rise and fall of European mercantilism}

At the start of the first millennium, Western Europe was the most peripheral region within Eurasia. Like Africa, its exports largely consisted of forest products and slaves, and it had direct economic links with just two other Eurasian regions, Eastern Europe and the Islamic world. By contrast, the Muslim world had direct economic contacts with all the regions of the then known world: Eastern and Western Europe, subSaharan Africa, the steppe societies of central Asia, and the highly developed civilisations of South Asia, Southeast Asia and East Asia (Findlay and O'Rourke 2007).

By the 18th century, Western Europe was no longer a peripheral appendage of the Eurasian landmass, but had become geographically and politically central. It was now in direct contact with all other regions of Eurasia, as well as with sub-Saharan Africa, but more importantly controlled both North and South America, which were fully integrated into the world economy, importing slaves from Africa, exporting a variety of colonial goods to Europe, and exporting silver both to Europe and to Asia via the Philippines. As for Eastern Europe, it was now in direct contact not just with central Asia and the Muslim world, but with East Asia and North America as well, as a result of Russia's Siberian conquests which would prove to be the most enduring of all the European imperialisms of that time.

In contrast to China, which was relatively self-sufficient, European merchants and states had a strong interest in seeking out direct routes to sub-Saharan gold deposits, thus bypassing the Muslim middlemen to the who controlled the trans-Saharan trade; purchasing African slaves, and using these on the sugar plantations of newly-discovered offshore African islands; and ultimately in circumnavigating Africa, reaching Asian spice markets directly, and again cutting out Muslim (and Venetian) middlemen. Once Columbus stumbled upon the Americas, Europeans had every incentive to exploit the vast resources of this New World as fully as possible. All of these activities were extremely lucrative, and the mutual dependence of Power and Plenty (Viner 1948) meant that states as well as merchants had a powerful motive to pursue them. Trade profited merchants, but also yielded revenues to the state; while the state needed revenues to secure trading opportunities for its merchants, by force if necessary. Trade and empire 
were thus inextricably linked in the minds of European statesman during the early modern period, which explains the incessant mercantilist warfare of the time.

The 18th century saw the gradual rise to pre-eminence of Britain in this struggle for power and plenty in the west, while Russia became dominant in the east. The Iberians continued their hold on Latin America, but the 17th century saw Portugal being replaced in the Indian Ocean and Southeast Asia by the Dutch. 1648 was an important turning point, marking the end of the long-standing war between the Netherlands and Spain. This freed up silver and soldiers, two essential "inputs" for the Dutch East India Company's activities in Asia, and facilitated a series of conquests in Ceylon, on the Malabar coast, and in the East Indies. By the late 17th century, the Dutch had succeeded in controlling the supply of spices such as cloves, leading to a dramatic reduction in their exports, and an end to Southeast Asia's "Age of Commerce". As Figure 4.1 shows, the Dutch maintained their dominant position in the European-Asian seaborne trade until the end of the 18th century. Meanwhile, the British found in India an abundant supply of several commodities, notably cotton textiles, which they exported not only to Europe, but to Africa and the Americas as well. By the third quarter of the 18th century, and after military victories at Plassey in 1757, and Buxar in 1764, the English East India Company was embarked on a path which would ultimately lead to dominion over the entire subcontinent. After the Bengal mutiny of 1857, India formerly became part of the British Empire.

In Western Europe, the triangular struggle for domination between the Netherlands, France and England became a bilateral struggle between the latter two powers following William of Orange's takeover of the British throne in 1688-1689. England and France fought during the Nine Years War (1689-1697), the War of the Spanish Succession (1701-1713), and the War of the Austrian Succession (1740-1748). The Seven Years War (1756-1763) was an important victory for Britain, which gained control of France's North American possessions as well as several islands and ports in the Caribbean and along the African and Indian coasts. In Eastern Europe, Russia under Peter the Great and Catherine the Great was strengthening her position as a great European power, defeating Sweden in the Great Northern War, absorbing the former Grand Duchy of Lithuania and much of Poland, and expanding to the south at the 
expense of the Tartar Khanates and the Ottoman Empire. Russia had already expanded eastwards as far as the Pacific by the middle of the 17th century; it now had secure footholds on both the Baltic and Black seas.

All these European powers pursued a variety of mercantilists policies, designed to enrich both the state and the local merchant class. These included protecting local industries against foreign competition, protecting the local shipping industry by preventing foreign merchants from trading with either the mother country or its colonies, and a variety of policies designed to extract as much profit as possible from those colonies. Empires yielded financial benefits by providing control over precious metal supplies (in Latin America); giving access to abundant supplies of slaves (Africa); allowing the cultivation of warm-climate crops such as tobacco and cotton, or trapping furs in colder climates, and selling these on to consumers in Europe (the Americas and North Asia); or allowing control over trade routes, or better yet the sources of supply of scarce commodities such as spices (in Asia).

Such considerations were also present at the time of the Ottoman expansion into Central and Eastern Europe, although the desire to spread Islam was another motivation, just as spreading Christianity was a concern of the early Iberian explorers. Booty, control over trade routes, and (in the 14th and 15th centuries) access to the silver mines of Serbia and Macedonia were all important motives for the Turks, and indeed the prospect of plunder can help to explain why many Christians fought on the Ottoman side.

Furthermore, the Ottomans actively intervened to prevent the Portuguese from obtaining a monopoly of the spice trade in the Indian Ocean, fighting the interlopers both directly along the Persian Gulf, and indirectly via their support for the sultan of Acheh, from where pepper continued to be exported to Ottoman-held territory, and from there to Venice. This allowed the Ottomans to continue enjoying the rents from the transit trade until the appearance of the Dutch and English in the Indian Ocean in the 17th century. The Ottomans were not mercantilists, in that they were not concerned with the interests of domestic merchants or producers, and correctly understood that imports were desirable, and that the fewer exports were needed to pay for these imports the better. However, they were also sensitive to the mutual dependence of Power and Plenty, which was a general feature of the Eurasian geopolitical landscape at a time when the Military 
Revolution was making warfare more expensive, and reducing the number of states that were militarily viable at any given time.

This mercantilist system was swept away in the early 19th century as a result of technological and geopolitical change. Paradoxically, the beginning of the end occurred in North America, partly at least as a result of British successes there. As a number of observers predicted following the end of the Seven Years War, without a French presence threatening the British colonists there, those colonists would now find it easier to press for independence from the mother country. The fiscal crisis which the conflict gave rise to provided one trigger for the American Revolution, which ended with the Peace of Paris in 1783. French involvement was crucial for the rebellion's success, but this in turn led to a fiscal crisis in France which again was one of the triggers leading to revolution there. When war between Britain and France broke out yet again in 1793, it now had an additional ideological dimension adding to the severity and duration of the conflict, which only finally ended with the French defeat at Waterloo in 1815. By that time, Napoleon's invasion of Iberia in 1807 had been followed by a series of revolutions in Latin America, and by the 1820s independent republics (or an empire in the case of Brazil), had been established across the continent. Apart from Spanish Cuba and Puerto Rico, and British Canada, virtually nothing remained of Europe's New World empires. While these newly independent nations adopted highly protectionist policies during the 19 th century, those tariffs would be imposed in the context of a broadly multilateral international trading system, in which there were no more bilateral mercantilist restrictions on trade.

Several other factors promoted globalisation between 1815 and 1870 . The postwar settlement, ushered in by the Congress of Vienna, led to a remarkably durable peace in Europe. Despite the Crimean War, the Franco-Prussian war, and a number of smaller conflicts, and despite the fact that the period ended with the disaster of the Great War, the century after Waterloo was a peaceful one by European standards. The new transport technologies of the Industrial Revolution, described in Chapter 1.8, dramatically reduced transport costs. Geopolitically, new industrial military technologies increased the relative power of Europe and her most important overseas offshoot, the United States. The halfcentury following Waterloo saw major European imperial advances in India, North 
Africa and elsewhere, as well as the infamous Opium Wars which forcibly opened Chinese markets to trade. Meanwhile, the United States expanded overland across North America, while Russia continued to expand in Asia. European states forced more or less free trade on their Imperial possessions or on nominally independent nations such as China, Japan and Siam.

The period also saw a gradual move towards trade liberalisation in Europe. Early liberalisers were typically smaller countries, such as the Netherlands and Denmark. The latter country had abolished import prohibitions and adopted low tariffs as early as 1797 , while the Dutch moved to a relatively liberal trade policy in 1819, having seen the Dutch East India Company being destroyed during the war. The first major economy to liberalise was Britain, where power was shifting to export-oriented urban interests. Liberal reforms in the 1820s and 1830s were followed by Robert Peel's historic decision to abolish the Corn Laws in 1846, and move the United Kingdom to a unilateral policy of agricultural and industrial free trade, against the objections of landlords and much of his own Tory party. There followed further moves towards liberalisation in countries such as Austria-Hungary, Spain, the Netherlands, Belgium, Sweden, Norway and Denmark (Bairoch 1989, pp. 20-36). For example, in 1849 Spain abolished its navigation laws and suppressed prohibitive tariffs, and the Spanish went on to liberalise imports of inputs into railway construction in the mid-1850s. Average tariffs were falling throughout the 1850s in the major European powers (Accominotti and Flandreau 2006).

Trade liberalisation was not universal. Russia and Austria-Hungary remained extremely protectionist throughout almost all the period, only liberalising slightly in the late 1860s. The Ottoman Empire actually became more protectionist during the period, not less, although this is explained by the fact that it had previously been limited to a maximum 3\% tariff as a result of various treaties signed with Western European powers. In 1838 , the Turks obtained the right to raise their tariffs to $5 \%$, but at the cost of abolishing all monopolies and prohibitions. Overall, however, the period between Waterloo and 1870 was one in which both trade policy and technology were integrating international commodity markets. The switch from mercantilism to modernity was now complete. 


\section{Quantitative trends, 1700-1870}

\subsection{Trade volumes}

Using the shipping data in Figure 4.1, Jan de Vries (2003) estimates that the tonnage returned from Asia to Europe grew at 1.01\% per annum during the 16th century, $1.24 \%$ during the $17 \mathrm{th}, 1.16 \%$ during the $18 \mathrm{th}$, and at $1.1 \%$ over the three centuries as a whole. O'Rourke and Williamson (2002a), using a more eclectic mix of data, calculate average growth rates per annum of European trade with both Asia and the Americas of $1.26 \%$ during the 16 th century, $0.66 \%$ during the 17 th, $1.26 \%$ during the 18 th, and $1.06 \%$ per annum overall. An average growth rate of roughly 1\% per annum over a period of three centuries was an impressive achievement relative to what had gone before, and led to Europe, or at least the maritime powers of Western Europe, becoming more open, albeit from very low levels. According to Maddison (2003), Western European GDP grew at roughly $0.4 \%$ per annum between 1500 and 1820 , implying rising ratios of intercontinental trade to GDP. ${ }^{1}$ As a result, trade with Asia, Africa and America was a very important share of European trade in 1790 (Table 4.1).

The wars of 1792-1815 and the Industrial Revolution were a turning point for European trade, dramatically increasing the relative importance of the United Kingdom (contrast Table 4.1 and Table.2 with Table 4.54.3), and reducing European trade to GDP ratios. Both phenomena are partly explained by the fact that pre-1800 trade to GDP ratios were inflated by entrepôt trade (Table 4.4.4) which declined following the end of the "first" French and Iberian colonial empires and the collapse of the Dutch East India Company. Trade started growing again during the 1830s. Between 1820 and 1870, the volume of trade grew ninefold (Table 4.5) and the European trade to GDP ratio more than doubled.

\subsection{Commodity market integration}

Perhaps surprisingly, the increase in early modern trade volumes between Europe and the rest of the world was not accompanied by commodity price convergence, at least according to the data that have been analysed up to now (O'Rourke and Williamson 2002b). Figure 4.2 shows that the ratio of the Amsterdam to the Asian prices for pepper

\footnotetext{
${ }^{1}$ The Maddison figures probably represent an upper bound, given the lower growth figures (around $0.1 \%$ per annum) calculated by van Zanden (2005) and Álvarez-Nogal and Prados de la Escosura (2007).
} 
and cloves did not fall before the 19th century, and there was substantial price divergence for cloves in the 1650s, coinciding with the establishment of Dutch control over clove supplies around that time. Mercantilist policies could have directly prevented price convergence during this period, as the figures for cloves suggest, but mercantilism also created an international political environment in which wars were frequent, and this was perhaps the key factor preventing long run price convergence. Peaks in the clove price gaps during the first and second Anglo-Dutch wars, the Seven Years War, and the wars of 1792-1815, lend credence to this view. More systematic price evidence is available for the latter conflict, and shows clearly that warfare led to a dramatic, worldwide disintegration of commodity markets (O'Rourke 2006). For example, the price of wheat rose by over 40\% during 1807-14 relative to textiles in Britain, which imported wheat and exported textiles, but it fell in France, which was a wheat exporter and cotton textile importer. Similarly the price of raw cotton rose relative to textiles in Europe, but fell substantially in the United States.

Figure 4.2 shows dramatic price convergence between Southeast Asia and the Netherlands once the wars had ended, and a vast array of evidence documents international price convergence more generally during the 19th century. Figure 4.3 shows that while the Anglo-American wheat price gap fluctuated widely before 1840 or so, around a roughly constant trend, it started to drop dramatically after that date, coinciding with the commencement of large-scale shipments of wheat between United States and Britain. Jacks (2005, p. 399) concludes that there is evidence of a "truly international market for wheat from around 1835". This evidence (cf. Federico and Persson 2007) is important, since it shows that international price convergence characterised the 19th century as a whole, not just the years after 1870 .

Another important change after 1800 concerns the types of commodities which could be transported profitably between continents. As Table 4.6 shows, European imports from the rest of the world before then were mostly high value-to-weight ratio commodities, which could bear the cost of transport because they were not produced in Europe at all, or only with some difficulty. There was a gradual evolution, to be sure. During the 16th century, silver and spices were the dominant imports from the Americas and Asia respectively. Around the middle of the 17th century Indian textiles became the 
leading European import from Asia, but the European textile industry was still uncompetitive relative to Indian weavers. Around the same time, "colonial goods" such as sugar and tobacco were becoming important New World exports, but these were warm-climate commodities that could not be easily grown in Western Europe. There was thus an evolution in the nature of intercontinental trade during the early modern period, towards bulkier commodities, but the period before 1800 did not, for the most part, involve large scale intercontinental trade in basic, heavy commodities such as wheat which could be easily grown both inside and outside Europe.

The new transport technologies of the 19th century meant that such basic, "competing" commodities could indeed be shipped across the oceans of the world. European prices for temperate climate agricultural commodities now started to reflect American, Australian and Russian factor endowments rather than demand and supply in Western Europe alone, implying that, in line with Heckscher-Ohlin logic, cheap overseas food started to place European land rents under pressure (O'Rourke and Williamson 2005). This would only become important in the years after 1870 , when these Heckscher-Ohlin forces would have important political repercussions. However, the seeds of that retreat from globalization were sown in the half century following Waterloo.

\section{Trade, empire and growth}

\subsection{Introduction}

Aggregate evidence suggests that trade was positively associated with growth in Europe during the 17th and 18th centuries. Both the urbanisation rate and GDP grew more rapidly in the "Atlantic" European economies (England, France, the Netherlands, Portugal and Spain) than in the rest of Western Europe or Asia between 1500 and 1800 (Acemoglu et al 2005, Maddison 2003). Allen (2003) also finds a strong positive relationship between trade and growth in Europe during this period, concluding that "the intercontinental trade boom was a key development that propelled north-western Europe forwards" (p. 432).

It is less clear what the mechanisms were linking trade with economic growth. Different authors, discussing the impact of trade on various European countries, tend to assume different mechanisms, while to make matters even more complicated the 
literature very often (if understandably, given the realities of mercantilism) conflates two conceptually distinct issues, namely the impact of trade in general, and the effects of countries' colonial policies. In what follows, we therefore look at the mechanisms through which, it has been suggested, trade might have influenced growth. We then consider the link between imperialism per se and economic welfare, using the Iberian loss of its Latin American colonies as a "natural experiment". Finally, we take a more detailed look at the various links between trade and the central economic event of this period, the British Industrial Revolution.

\subsection{Mechanisms}

How might trade have affected growth during this period? One crucial issue is whether or not all resources in the economy were fully employed. With full employment, allocating resources to exports had an opportunity cost, as they could alternatively have been used in production for the domestic market. While a "comparative advantage" perspective leads to the conclusion that trade was beneficial for economies, it also tends to imply that the gains involved were small (since the Harberger triangles measuring the

gains of moving to free trade from some protectionist equilibrium are small relative to the size of the overall economy). Thus Thomas and McCloskey (1981) among others conclude that if the British economy had been shut off from trade at the time of the Industrial Revolution, it would have produced a lot less cotton, but a lot more of other commodities, and sustained only a small welfare loss.

An alternative Smithian "vent for surplus" perspective assumes that resources in many 18th century economies were unemployed, or at least underemployed, and that trade could bring these resources into productive (or more productive) employment at little or no opportunity cost. In this case, trade would have a bigger effect on economic growth, as O'Brien and Engerman (1991) argue for the British case. Faced with these two alternatives, some researchers have adopted the eclectic solution of providing upper (unemployment) and lower (full employment) bounds for the impact of trade or empire on particular economies. Nevertheless, both approaches tend to produce small numbers, with the estimated contribution of empire or trade to growth remaining modest compared with the expansion of the domestic market. This is not surprising, since both approaches 
are essentially static, whereas economic growth is a dynamic process, involving both capital accumulation and technological change.

While any rigorous assessment of the impact of trade on economic growth requires specifying a theoretical model, be it static or dynamic, many traditional economic historians have preferred to give qualitative accounts emphasising the impact of trade on particular regions or sectors. In the case of 18th century France, for example, Butel and Crouzet (1998) have depicted imperial expansion in (and thus trade with) America and Asia as a non-negligible contribution to growth, that was however concentrated both by region -- in the Atlantic ports (Bordeaux, Nantes, Le Havre) and their immediate hinterlands -- and by sector. Colonies represented a significant market for French industry, since they accounted for $45 \%$ of the total increase in manufactured exports during the 18th century. While such figures should be tempered by the fact that on the eve of the French Revolution exports only represented 7\% of industrial output, and colonial exports even less (only 2.5\%), the impact of these exports was concentrated in a few sectors (linen especially), implying proportionately greater effects there. Similarly, around $15 \%$ of Portuguese linen output was exported to Brazil in the early 19th century (Pedreira 1993). Butel and Crouzet also stress the feedbacks from colonial trade to nonexporting industries, including sugar refining, shipbuilding and its ancillary activities, as well as to the shipping industry, since transportation was on French ships.

In the case of Spain, trade with America increased between 1714 and 1796, especially during the late 18th century, promoting monetisation and market orientation at a time of growing population pressure and rising land rents. Trade stimulated industry and services, in particular shipbuilding and its associated activities (iron, timber and cordage industries). Exports to the colonies benefited some industries and regions, but the small share of industrial goods and commercial services supplied to Latin America by Iberian firms and merchants before the break up of their empires stands in contrast to the linkages forged between the British economy and her overseas territories and markets. Monetisation, the commercialisation of agriculture and the stimulus of particular industries, such as the iron industry, are also seen as major benefits of foreign trade in Russia during this period (Kahan 1985). 
Recent research has downplayed Spanish gains from colonial trade (Prados de la Escosura 1993). The composition of trade suggests that the possibility of increasing production by reallocating resources was small, and that most gains possibly resulted from changing consumption patterns. By 1792 , over $60 \%$ of retained imports consisted of cocoa and sugar. Furthermore, these colonial products could have been acquired on international markets. Consequently, gains from colonial trade would only occur if, given colonial rule, Spain acquired the same commodities at lower prices. Furthermore, Spain's dependence on the colonies for raw materials was very small (raw cotton and dyestuffs only represented $4 \%$ of retained imports in 1792). This is of course a measure of the weakness of domestic manufacturing. In the Catalan cotton textile industry (one of the most dynamic industries at the end of the 18th century), European cotton yarn imports were more important than colonial raw cotton imports, suggesting how weak the Catalan spinning industry was at the time.

Industrial exports, concentrated in a few sectors (textiles: $36.6 \%$ in 1792 ; iron and steel: $3.2 \%$; paper: $4.4 \%$; and food: $22.3 \%$ ) stimulated industrial expansion and were associated with some external economies in their regions of origin. Colonial protectionist legislation made Spanish manufactures artificially competitive on the Spanish American market. An upper bound computation suggests that exports of domestic manufactures to the colonies made a $5 \%$ contribution to industrial value added before the Napoleonic Wars (ibid).

One way of gauging the importance of overseas trade to the economies of Western Europe is to see what happened when the trade between Continental Europe and the Americas was suppressed by British blockades after 1807. Crouzet (1964, p. 571) presents a vivid picture of a deindustrializing Western European seaboard during this period: "Harbors were deserted, grass was growing in the streets, and in large towns like Amsterdam, Bordeaux, and Marseilles, population did actually decrease..." Industries which particularly suffered included shipbuilding, and those processing colonial raw materials such as sugar and tobacco. A variety of food-processing industries were also badly affected, as well as cotton printing, but the most important victim was the linen industry in regions like Western France, Flanders, Holland and Germany. According to Crouzet (p. 573), the damage done to the outward-oriented Atlantic economy of 
Continental Western Europe was permanent. On the other hand, trade disruption also led to the development of import substituting industries protected from British competition by wartime blockades, notably the cotton textile industry. To repeat, in a world with scarce resources which can be transferred from one activity to another, there is a limit to how great can be the static welfare losses associated with trade disruption, unless one assumes asymmetries across sectors (for example, associated with externalities: Engerman 1998).

Daudin (2006) abandons this essentially static perspective in favour of a more dynamic one, focused on profits and capital accumulation. The question he addresses is the extent to which colonial profits contributed to capital formation in France before the Revolution. Net re-invested profits linked to the overseas sector represented up to $6 \%$ of French savings, and were responsible for approximately $7 \%$ of French GDP per capita growth between 1715 and 1790 . This implies that by 1790 GDP would have been only $3 \%$ smaller in their absence. However, a further conjectural exercise (Daudin 2004), assuming that high overseas profits encouraged investment throughout the economy, suggests that they might have been responsible for as much as one-third of French growth.

A very different mechanism linking trade and growth was proposed by Voltaire more than two centuries ago. He argued that Britain's success in trade and the freedom of her constitution mutually reinforced each other in a virtuous circle: "trade, which has made richer the citizens of England, has helped to make them free, and this freedom has, in turn, enlarged trade" (cited in Findlay and O'Rourke 2007, p. 347). Similarly, Acemoglu et al. (2005) claim that Atlantic trade strengthened the political power of merchants, who obtained a strengthening of property rights in consequence. According to these authors, these beneficial political consequences of trade did not occur in states which had initially been more absolutist than, say, Britain, and there is a case to be made that imperialism strengthened rather than weakened absolutist monarchs in Iberia at this time. In early modern Europe state power was constrained by the Crown's needs to raise taxes. The more kings depended on taxes, the less sovereign and autonomous they became. Colonial revenues allowed the rise of a strong political centre which concentrated power without being drawn into extensive bargaining with its more 
prominent subjects and institutions. In Portugal, the tax on gold accounted for some $10 \%$ of public revenue in 1716, while by the 1760s, just before the gold and diamond mines started to decline, it provided a fifth of state receipts. Brazil supplied around $40 \%$ of government tax returns at the time of the Marquis of Pombal. In Spain, prior to the Napoleonic wars, Crown revenues of colonial origin (including the surplus from colonial chests and those derived from customs duties) represented one-fourth of the total. In Spain, as in Portugal, bullion not only underpinned regal power but augmented the incomes of the aristocracy, and thereby reduced their need to increase taxation and rents from the population. Thus, the colonial empire helped to consolidate and stabilise traditional institutions and structures of power, status and property rights within Iberia, implying comparatively few representative institutions there.

The emancipation of the American colonies at the start of the 19th century marked the end of the Iberian Ancien Regime, and opened the way to liberal revolutions in Spain and Portugal with implications for the economic development and international position of Iberia that have remained largely unexplored. Accounts of economic backwardness in 19th century Iberia have often placed the blame on the loss of empire, but this may in fact have contributed significantly to the economic and social modernisation of the peninsula.

\subsection{Empires and welfare}

The question of why European countries chose to build empires has long been controversial. Several hypotheses have been proposed, ranging from the purely economic to the purely political, with several intermediate cases as well. Among the more economic explanations is the Vinerian view which we have already encountered that in the absence of integrated international markets, caused largely by insecurity in an age of widespread piracy and warfare, overseas expansion permitted the creation of reserved markets, thus intertwining conquest and trade. If Spanish merchants, say, were to be able to trade in a given area, the Spanish government would have to make this possible by excluding other merchants and governments from that area, since otherwise the Spanish would themselves be excluded. This is not to deny that a generally free trading situation would have been preferable to one in which each country pursued a mercantilist strategy, 
which might have been individually rational, from a military or even economic viewpoint, but which produced a collectively suboptimal outcome. From a historical point of view however one can ask: is this a realistic counterfactual, in a world without a collective security regime? Findlay and O'Rourke (2007, p.257) argue that for the individual European state, pondering what such a unilateral conversion to peaceful free trade might bring, "in the absence of... a clearly defined hegemonic power, military defeat and exclusion from foreign markets" seems a plausible answer.

Other less economic explanations for empire have also been proposed. For example, in response to the question as to why, once the technological constraints that impeded long-distance oceanic voyages had been removed, only some European countries established colonies overseas, Elliott (1990) proposed an explanation based on previous histories of expansion. Iberian plunder, settlement, and colonisation in the Americas, in this view, represented a follow-up to the reconquest ("reconquista") of territories previously under Muslim control, while England's overseas expansion in the 17 th century followed the conquest of Ireland in the previous century. Why did other countries in Europe eventually join them? Here Elliott points to competition between European nation-states, which triggered an emulation process leading to the seizure and occupation of New World lands. In this scenario, the fact that all of Europe ultimately became involved in overseas expansion was at least in part unintended.

Another view points to the interconnections between empire and nation-state building, with countries in Europe struggling not to be left behind. This interpretation regards as economistic and anachronistic the view that states and merchants needed reserved markets and supply sources in an uncertain world, and regards colonies not as an investment, but rather as costs paid for non-economic ends (Engerman 1998). The costs of empire are undeniable, since colonies needed to be acquired, settled, and defended. Wars, losses of life and ships represented -- from a purely economic perspective -- a diversion of resources from alternative uses. War costs had to be financed through taxes, inflation or public debt. Besides, the colonial system involved navigation laws that imposed an implicit tax on consumers, as they usually had to pay a price above that of the most efficient producer. 
A recurring theme in the Iberian literature is whether Portugal and Spain did not develop because, in building their empires, the metropolitan economy was disregarded. Did empires represent a significant opportunity cost, absorbing resources that could have been allocated to productive investment (Fontana 1991), or were such costs a prerequisite for economic development? In order to realise the potential inherent in the discovery of the resource-abundant but labour-scarce Americas, the Iberian powers required continuous investment in social overhead capital (ports, roads, housing, internal transportation, and oceanic shipping) and the establishment of new political and commercial organisations. This task was mainly undertaken by Iberians, while benefiting the rest of Europe, for at least 150 years after Columbus (O'Brien and Prados de la Escosura 1998). In the case of Portugal, it might be argued that emigration deprived the country of manpower, skills and entrepreneurship, since emigrants were young males, and more literate and ambitious than average. On the other hand, emigration made possible the colonisation of new territories, opening new markets and providing luxuries and tropical groceries at lower cost. Furthermore, emigration eased economic conditions in the more densely populated areas, especially in the northwest.

Ironically, in the light of this literature, it may be the flow of resources from the Americas to Iberia that did the most damage to the Spanish and Portuguese economies in the long run. First, as we have already seen, bullion flows strengthened absolutist monarchies and central governments, with damaging political and economic consequences. Second, the inflow of specie, gold in Portugal and silver in Spain, may have provoked a "Dutch disease" of sorts, damaging the competitiveness of local manufacturing industries (Forsyth and Nicholas 1983; Drelichman 2005).

One way of assessing the importance of empire to the Iberian economies is to explore what happened after the loss of those empires. By 1827, once Brazil had severed her links to Portugal and declared full independence, real Portuguese domestic exports represented just two thirds of their average level in 1796/1806. However, this conceals a switch from industrial to agricultural exports, with Portugal reorienting its economy towards Britain by selling its primary produce in exchange for manufactures, within the context of an improving terms of trade. Services suffered more, contracting by one fifth in real terms between the same dates. For example, Portugal could no longer be an 
entrepôt for the produce of Brazil. Pedreira (1993) suggests that the loss of Brazil implied an upper bound loss of $8 \%$ of GDP. A widespread consensus views Portugal as being now confined to the role of supplier of foodstuffs and raw materials, with no opportunities to specialise within the more dynamic industrial sector. However, since the old colonial system did not bring Portugal to the verge of modern industrialisation, its breakdown can hardly be blamed for the country's failure to subsequently industrialise.

In contrast to Great Britain and the thirteen North American colonies, where commercial links were immediately and vigorously renewed after their independence (Shepherd and Walton 1976), Spain and the new Latin American republics practically cut ties (except for the trade using Cuba as an entrepôt). From the beginning of the war with Britain in October 1796, Spain maintained almost no link with the colonies for more than two decades. The subsequent decline in domestic exports (roughly 25\% between 1784/96 and $1815 / 20$ ) can be attributed almost exclusively to the fall in colonial commerce (which shrank by $40 \%$ ). The consequence was the end of the long-standing equilibrium distribution of domestic exports between the colonies and Europe (roughly one-third and two-thirds, respectively), and the establishment of a new distribution that continued throughout the $19^{\text {th }}$ century (with foreign markets absorbing four-fifths). Retained imports of colonial goods for domestic consumption (which had represented one-third of total retained imports) were halved, but this was offset by imports from Europe. The collapse of trade with the empire was particularly significant for services (financial, insurance, transportation), as is revealed by the contraction of real re-exports by threefifths between 1784/96 and 1815/20. The Spanish balance of trade also felt the effects of colonial independence. Before the loss of empire, Spain had a deficit on current account with foreign countries that was balanced by a corresponding surplus in colonial trade. With colonial emancipation this balancing mechanism disappeared, with deflationary consequences for the domestic economy. Fortunately, a favourable terms of trade resulting from an improvement vis-à-vis Europe, more than matching a deterioration with respect to the colonies -- increased the purchasing power per unit of exports by $20 \%$ between 1784/96 and 1815/20, allowing Spain to avoid further deterioration in the current account balance. 
Prados de la Escosura (1993) has attempted a rough estimate of the real cost to Spain of the loss of her colonies, making assumptions favourable to the generally accepted view that the loss was significant. The first assumption is that the productive resources embodied in exportables did not have alternative uses in the domestic economy. A similar assumption is made regarding the services (shipping, insurance, mercantile) provided by Spanish subjects in the colonial trade. In contrast to the noncolonial trade, almost totally carried on non-Spanish ships, Spanish colonial legislation ensured that the Indies trade used only national shipping. Therefore, with the decline of Spanish American trade, a decline in Spanish maritime services closely followed. The loss in revenues due to the cessation of precious metal shipments, and the reduction of customs duties resulting from colonial independence, were also taken into account, the assumption being that public revenues from the colonies were productively used in the domestic economy. The upper bound estimate of Spanish losses implied by these assumptions was not more than $8 \%$ of national income. And while it could be argued that the profits from colonial trade represented a high proportion of the funds used to finance investment in Spain, an upper bound estimate of their contribution made to total capital formation is below $18 \%$ by $1784 / 96$.

The long term consequences of the loss of the colonies depended on the flexibility and dynamic nature of the industry concerned. The decline in manufactured exports from many sectors illustrates the lack of competitiveness of Spanish industries: Spain could not offer the Latin American consumer either the prices or the quality of her Western European competitors, specifically Great Britain. For example, the Basque iron and steel industry (which sold at least a third of its output to colonial markets at the end of the 18th century) became uncompetitive from the 1770s onward. A similar situation characterised the Valencia silk industry. Between the 1790s and the 1820s net exports of raw silk rose while net imports of silk textiles increased. Catalan shipping was yet another industry which had grown under colonial protection and suffered afterwards. However, Catalan cotton textiles developed further once the colonial market had been lost. The more competitive and flexible sectors of the economy eventually adapted to new circumstance, particularly commercial agriculture which turned towards growing markets in Western Europe. As mentioned earlier, the 19th century was a good time to do this, in that the 
terms of trade moved favourably for agricultural producers, with technological progress lowering the prices of industrial goods and growing demand raising relative agricultural prices (Figure 4.4). The loss of the colonies had a less profound and widespread impact upon the Spanish economy than the historical literature has suggested.

\subsection{Trade and the Industrial Revolution}

Chapter 1 provided a broad overview of Europe's transition to modern economic growth. We now focus on one particular aspect of this transition, and ask: what was the impact of trade and empire on the British Industrial Revolution? The literature on this issue has largely been shaped by the dominant economic theories of the day. One particularly influential strand of thought has been inspired by the assumption of Classical economists, from Smith to Marx, that growth depends on investment, which depends on savings, which depends on profits (since workers were assumed to be too poor to save, and landlords too frivolous). In a famous book, Eric Williams (1966) argued that Atlantic slave trade profits financed the Industrial Revolution. His largely anecdotal evidence consisted of enumerating cases in which those associated with slavery made investments in domestic British industry. The classic quantitative responses to Williams were made by Engerman (1972) and O'Brien (1982), both of whom measured the profits associated with the slave trade (or, in the case of O'Brien, with Britain's trans-oceanic activities more generally), and found these to have been too small to have possibly mattered. For example, O'Brien found that the total profits accruing to those engaged in trade and commerce with the 'periphery' in 1784-86 amounted to $£ 5.66$ million. If $30 \%$ of these profits were saved and reinvested, then that would have financed roughly $15 \%$ of British gross investment during that period. Since 15\% was, for O’Brien, a small figure, the Williams thesis 'foundered on the numbers' (p. 16).

There is a more fundamental problem with the Williams thesis, which is that as we saw in Chapter 1, technological change rather than capital accumulation was the driving force behind the Industrial Revolution. By focussing on profits as the possible link between overseas trade, empire and slavery on the one hand, and European growth on the other, Williams and others have been barking up the wrong channel. If Marxist economic theory is ill-suited to explain the Industrial Revolution, then so too is 
Keynesian theory, by definition, since Keynes was concerned with the short run determination of output and employment, not with long run economic growth. This has not prevented various historians from attempting to argue that overseas demand exogenously boosted British industrial output during the transition to modern growth. As almost $60 \%$ of British cotton textile exports went to non-European countries during 17846 (Davis 1979), such a claim is understandable. However, growth is ultimately a supplyside phenomenon, and indeed if growth had been due to rising overseas demand, then Britain's terms of trade should have increased during the Industrial Revolution, whereas in fact they fell, reflecting the cost-reducing nature of the innovations concerned (McCloskey 1981, Mokyr 1977). Figure 4.5 makes the point in a simple manner. According to Crafts and Harley (1992), industrial output rose by roughly $235 \%$ between 1780 and 1831, while GDP rose by roughly $135 \%$. If the income-elasticity of demand was unity, and foreign incomes rose at the same rate as British ones, then the demand for British manufactures at constant prices rose by roughly $135 \%$. This can be illustrated by the outward shift of demand from D to D' (ignore D" and D"' for now). If the industrial supply curve were vertical, it would have shifted out by $235 \%$, intersecting D' at the new equilibrium, denoted by point $\mathrm{B}$. The available data on the British terms of trade suggest that at this point, relative manufactured goods prices were (very roughly speaking) $55 \%$ lower than in the initial equilibrium A. If the elasticity of supply were unity, on the other hand, the supply curve would have shifted out (at constant prices) by $290 \%$ $(=135+100+55)$, far more than the $135 \%$ outward shift in demand.

Findlay (1990) provides a simple general equilibrium model of the late $18^{\text {th }}$ century Atlantic economy which, although it is static, can still help in thinking about how trade really mattered during the Industrial Revolution. That revolution was initially heavily concentrated in cotton textiles, and British imports of raw cotton came exclusively from outside Europe, and particularly from the Americas. The American supply was highly elastic, as a result of the then seemingly limitless endowment of New World land, and the highly elastic supply of slave labour. The Industrial Revolution meant a large increase in the demand for raw cotton, and hence a rise in its price at home and abroad, implying a deterioration in Britain's terms of trade. High American supply elasticities minimised this terms of trade loss - in the absence of slaves and New World 
land, relative raw cotton prices would have increased by more than they actually did, potentially choking off growth in this crucial sector. The existence of overseas markets also implied a higher demand for cotton textiles, and a more elastic demand as well. As can be seen from Figure 4.5, a given supply shift due to industrial innovation would have had a smaller output effect, and reduced cotton textiles prices by even more than was actually the case, with inelastic demand (compare the shift from D to D' with the shift from $\mathrm{D}$ " to D"').

Not only did trade ensure that a given supply side impulse travelled further; it also probably ensured more innovation, which was both motivated by profits and expensive (Allen 2006). Large fixed research and development costs implied that innovators had to make profits just to break even, and larger markets helped innovators recoup those fixed costs. Furthermore, under certain circumstances larger markets imply more elastic demand curves for individual monopolistically competitive firms (Desmet and Parente 2006). Thus a given price-reducing innovation will imply larger sales and revenue increases in larger markets, meaning that as markets expand, innovation becomes more likely. While this mechanism has yet to be quantified, presumably a closed Britain (even a closed Britain miraculously enabled to grow cotton) would not have experienced as much innovation as was in fact observed. Unlike China or the Mughal Empire, it was too small to rely on its domestic markets. As it was, increases in exports were equivalent to $21 \%$ of the total increase in GDP between 1780 and 1801 Crafts (1985, p. 131), over 50\% of additional industrial output during the same period (Cuenca Esteban 1997), and over 60\% of additional textiles output between 1815 and 1841 (Harley 1999, p. 187).

Furthermore, by the late 18th century manufacturing was spreading across Western Europe, and English manufacturers were finding themselves increasingly excluded from markets in Germany, France, Sweden and elsewhere (Davis 1962). Not surprisingly, therefore, between 1780 and 1801 the Americas accounted for roughly $60 \%$ of additional British exports (O’Brien and Engerman 1991, p. 186). British innovators were largely dependent on overseas markets as their industries expanded. The implication, in a mercantilist world in which nations systematically excluded their enemies from protected markets, is that British military success over the French and other European rivals was one ingredient in explaining her subsequent rise to economic 
prominence: certainly not a sufficient condition, since domestic conditions had to be right in order to spur innovation in the first place, but possibly a necessary one. 


\section{References}

Accominotti, O. and M. Flandreau. 2006. Does Bilateralism Promote Trade? Nineteenth Century Liberalization Revisited. CEPR Discussion Paper 5423.

Acemoglu, D., S. Johnson and J.A. Robinson. 2005. The Rise of Europe: Atlantic Trade, Institutional Change and Economic Growth. American Economic Review 95: 546-579.

Allen, R.C. 2003. Progress and Poverty in Early Modern Europe. Economic History Review 56: 403-443.

Allen, R.C. 2006. The British Industrial Revolution in Global Perspective: How Commerce Rather than Science Caused The Industrial Revolution and Modern Economic Growth. Mimeo, Oxford University.

Álvarez-Nogal, C. and L. Prados de la Escosura, 2007. The Decline of Spain (15001850): Conjectural Estimates. European Review of Economic History 11:319-366.

Arnould, A.M. 1791. De la balance du commerce et des relations commerciales extérieures de la France dans toutes les parties du globe particulièrement à la fin du règne de Louis XIV et au moment de la Révolution. Paris: Buisson.

Bairoch, P. 1989. European Trade Policy, 1815-1914. In The Cambridge Economic History of Europe, Volume VIII, The Industrial Economies: The Development of Economic and Social Policies, ed. P. Mathias and S. Pollard. Cambridge: Cambridge University Press.

Bulbeck, D., A. Reid, L.C. Tan and Y. Wu. 1998. Southeast Asian Exports since the 14th Century: Cloves, Pepper, Coffee and Sugar. Leiden: KITLV Press.

Butel, P. and F. Crouzet. 1998. Empire and Economic Growth: the Case of 18th Century France. Revista de Historia Económica 16: 177-193.

Crafts, N.F.R. 1985. British Economic Growth during the Industrial Revolution. Oxford: Oxford University Press.

Crafts, N.F.R. and C.K. Harley. 1992. Output Growth and the British Industrial Revolution: A Restatement of the Crafts-Harley View. Economic History Review 44: 703-730.

Crouzet, F. 1964. Wars, Blockade, and Economic Change in Europe, 1792-1815. Journal of Economic History 24: 567-588.

Cuenca Esteban, J. 1989. "The Markets of Latin American Exports, 1790-1820: A Comparative Analysis of International Prices," in L.L. Johnson and E. Tandeter (ed.), Growth and Integration in the Atlantic Economy University of New Mexico Press. 
Cuenca Esteban, J. 1997. The Rising Share of British Industrial Exports in Industrial Output, 1700-1851. Journal of Economic History 57: 879-906.

Daudin, G. 2004. Profitability of Slave and Long Distance Trading in Context: The Case of 18th Century France. Journal of Economic History 64: 144-171.

Daudin, G 2005. Commerce et prospérité: la France au XVIIIe siècle. Paris: PUPS.

Daudin, G. 2006. Do Frontiers Give or Do Frontiers Take? The Case of Intercontinental Trade in France at the end of the Ancien Régime. In O. Pétré-Grenouilleau, P. Emmer and J. Roitman (ed.), A Deus Ex Machina Revisited. Atlantic Colonial Activities and European Economic Development, Brill.

Davis, R. 1962. English Foreign Trade 1700-1774. Economic History Review 15: 285303.

Davis, R. 1969. English Foreign Trade (1700-1774). In W. E. Minchinton (ed.), The Growth of English Overseas Trade in the Seventeenth and Eighteenth Centuries. London: Methuen.

Davis, R. 1979. The Industrial Revolution and British Overseas Trade. Leicester: Leicester University Press.

Deane, P. and W.A. Cole. 1962. British Economic Growth 1688-1959 : Trends and Structure. Cambridge: Cambridge University Press.

Desmet, K. and S.L. Parente. 2006. Bigger is Better: Market Size, Demand Elasticity and Resistance to Technology Adoption. CEPR Discussion Paper 5825.

Drelichman, M. 2005. The curse of Moctezuma: American Silver and the Dutch Disease. Explorations in Economic History 42: 349-380.

Elliott, J.H. 1990. The Seizure of Overseas Territories by European Powers. In H. Pohl (ed.), The European Discovery of the World and its Economic Effects on Pre-Industrial Society, 1500-1800, Vierteljahrschrift für Sozial-und Wirstchaftsgeschichte 89: 43-61.

Engerman, S.L. 1972. The Slave Trade and British Capital Formation in the Eighteenth Century: A Comment on the Williams Thesis. Business History Review 46: 430-443.

Engerman, S.L. 1998. British Imperialism in a Mercantilist Age, 1492-1849: Conceptual Issues and Empirical Problems. Revista de Historia Económica 16: 195-233.

Findlay, R. 1990. The Triangular Trade and the Atlantic Economy of the Eighteenth Century: A Simple General Equilibrium Model. Essays in International Finance177. Princeton: Princeton University Press. 
Findlay, R. and K.H. O'Rourke. 2007. Power and Plenty: Trade, War, and the World Economy in the Second Millennium. Princeton: Princeton University Press.

Fontana, J. 1991. La crisis colonial en la crisis del Antiguo Régimen español. In H. Bonilla, (ed.), El sistema colonial en la América española. Barcelona: Ariel.

Forsyth, P. J. and Nicholas, S. J. 1983. The Decline of Spanish Industry and the Price Revolution: a Neoclassical Analysis. Journal of European Economic History 12: 601610.

Harley, C.K. 1999. Reassessing the Industrial Revolution: A Macro View. In The British Industrial Revolution: An Economic Perspective, Second Edition, ed. J. Mokyr. Boulder: Westview Press.

Jacks, D.S. 2005. Intra- and International Commodity Market Integration in the Atlantic Economy, 1800-1913. Explorations in Economic History 42:381-413.

Kahan, A. 1985. The Plow, the Hammer and the Knout. Chicago: University of Chicago Press.

Maddison, Angus. 2001. The World Economy: A Millenial Perspective. Paris: OECD.

Maddison, A. 2003. The World Economy: Historical Statistics. Paris: OECD.

Marczewski, J. 1961. Some Aspects of the Economic Growth of France, 1660-1958. Economic Development and Cultural Change, 9: 369-386.

Marshall, J. 1833. A Digest of All Accounts. London.

McCloskey, D.N. 1981. The Industrial Revolution, 1780-1860: A Survey. In R. Floud and D.N. McCloskey (eds.), The Economic History of Britain since 1700. I 1700-1860, Cambridge: Cambridge University Press.

McCusker, J. J. 1978. Money and Exchange in Europe and America, 1650-1775: A Handbook. Chapel Hill: University of North Carolina Press.

Mokyr, J. 1977. Demand vs. Supply in the Industrial Revolution. Journal of Economic History 37: 981-1008.

O'Brien, P.K. 1982. European Economic Development: The Contribution of the Periphery. Economic History Review 35: 1-18.

O'Brien, P.K. and S.L. Engerman. 1991. Exports and Growth of the British Economy from the Glorious Revolution to the Peace of Amiens. In B.L. Solow (ed.), Slavery and the Rise of the Atlantic System. Cambridge: Cambridge University Press. 
O'Brien, P.K. and L. Prados de la Escosura. 1998. The Costs and Benefits for Europeans from their Empires Overseas. Revista de Historia Económica 16: 29-89.

Officer, L. H. 2001. Comparing the Purchasing Power of Money in Great Britain from 1264 to Any Other Year Including the Present. http://www.eh.net/hmit/ppowerbp/.

O'Rourke, K.H. 2006. The Worldwide Economic Impact of the French Revolutionary and Napoleonic Wars, 1793-1815. Journal of Global History 1: 123-149.

O'Rourke, K.H. and J.G. Williamson. 2002a. After Columbus: Explaining the Global Trade Boom 1500-1800. Journal of Economic History 62: 417-456.

O'Rourke, K.H. and J.G. Williamson. 2002b. When did Globalization Begin? European Review of Economic History 6: 23-50.

O'Rourke, K.H. and J.G. Williamson. 2005. From Malthus to Ohlin: Trade, Industrialisation and Distribution Since 1500. Journal of Economic Growth 10: 5-34.

Pedreira, J.M. 1993. La economía portuguesa y el fin del imperio luso-brasileño. In L. Prados de la Escosura and S. Amaral (eds.), La independencia americana: consecuencias económicas, Madrid: Alianza.

Prados de la Escosura, L. 1988. De imperio a nación: Crecimiento y astraso económico en España (1780-1930). Madrid: Alianza.

Prados de la Escosura, L. 1993. La pérdida del imperio y sus consecuencias económicas. In L. Prados de la Escosura and S. Amaral (eds.), La independencia americana: consecuencias económicas, Madrid: Alianza.

Prados de la Escosura, L. 2000. International Comparisons of Real Product, 1820-1990: an Alternative Dataset. Explorations in Economic History, 37: 1-41.

Prados de la Escosura, L. Mimeo. Terms of Trade between Spain and Britain, 1714-1913: Testing the Prebisch Hypothesis during the Industrial Revolution

Romano, R. 1962. Per una valutazione della flotta mercantile europea alla fine del secolo XVIII. In A Giuffé (ed.), Studi in onore di Amintore Fanfari. Milano: A. Giuffrè.

Shepherd, J.F. and G.M. Walton. 1976. Economic Change after the American Revolution. Explorations in Economic History 13: 397-422.

Thomas, R.P. and D.N. McCloskey. 1981. Overseas Trade and Empire, 1700-1860. In R. Floud and D. McCloskey (eds.), The Economic History of Britain since 1700. I 17001860, Cambridge: Cambridge University Press. 
Viner, J. 1948. Power Versus Plenty as Objectives of Foreign Policy in the Seventeenth and Eighteenth Centuries. World Politics 1: 1-29.

Vries, J. de. 2003. Connecting Europe and Asia: A Quantitative Analysis of the CapeRoute Trade, 1497-1795. In D.O. Flynn, A. Giráldez and R. von Glahn (eds.), Global Connections and Monetary History, 1470-1800. Aldershot: Ashgate.

Vries, J. de and A. M. van der Woude. 1997. The First Modern Economy : Success, Failure, and Perseverance of the Dutch Economy, 1500-1815. Cambridge: Cambridge University Press.

Williams, E.E. 1966. Capitalism and Slavery. New York: Capricorn.

Zanden, J.L. van. 2005. Cobb-Douglas in Pre-Modern Europe. Simulating Early Modern Growth. IISH Working Paper. 
Table 4.1. European trade c. 1790 ( $\mathfrak{E}$ million)

\begin{tabular}{|c|c|c|c|c|c|c|c|c|}
\hline & \multicolumn{2}{|c|}{ Imports } & \multicolumn{2}{|c|}{ Exports } & \multirow{2}{*}{ 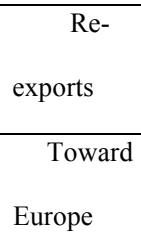 } & \multirow{2}{*}{$\begin{array}{c}\text { Re- } \\
\text { exports } \\
\text { Toward } \\
\text { ROW }\end{array}$} & \multirow[t]{2}{*}{ Total } & \multirow[t]{2}{*}{$\begin{array}{l}\text { Share } \\
\text { ROW }\end{array}$} \\
\hline & $\begin{array}{l}\text { From } \\
\text { Europe }\end{array}$ & $\begin{array}{l}\text { From } \\
\text { ROW }\end{array}$ & $\begin{array}{l}\text { Toward } \\
\text { Europe }\end{array}$ & $\begin{array}{l}\text { Toward } \\
\text { ROW }\end{array}$ & & & & \\
\hline $\begin{array}{l}\text { Britain (1784/86) } \\
\text { (Including trade } \\
\text { with Ireland) }\end{array}$ & 11.3 & 11.5 & 6.3 & 7.3 & 2.8 & 0.8 & 40.0 & $49 \%$ \\
\hline France (1787) & 12.8 & 11.7 & 9.7 & 5.3 & 6.0 & 0.4 & 45.9 & $38 \%$ \\
\hline $\begin{array}{l}\text { Netherlands (using } \\
1770 \text { trade } \\
\text { composition) }\end{array}$ & 9.3 & 3.6 & $\begin{array}{l}8.3 \\
\quad \text { (incl. } \\
\text { re-X) }\end{array}$ & $\begin{array}{l}0.7 \\
\quad \text { (incl. } \\
\text { re-X) }\end{array}$ & \multicolumn{2}{|c|}{$\begin{array}{l}3.8 \text { (colonial goods) } \\
2.4 \text { (European goods) }\end{array}$} & 21.9 & $20 \%$ \\
\hline $\begin{array}{l}\text { Spain (1788/92) } \\
\text { (ROW: America) }\end{array}$ & 3.6 & 2.0 & 3.5 & 1.9 & 1.4 & 2.2 & 19.0 & $36 \%$ \\
\hline $\begin{array}{l}\text { Portugal } \\
(1796 / 1800) \\
\text { (ROW: Brazil) }\end{array}$ & 4.1 & 2.9 & 1.4 & 1.3 & 3.9 & 1.4 & 15.3 & $35 \%$ \\
\hline
\end{tabular}

Sources: See Table 4.3 , and Pedreira (1993), Cuenca-Esteban (1989); Marshall (1833) 
Table 4.2. European merchant fleet c. 1790

\begin{tabular}{lcc}
\hline & Tons & Percentage \\
\hline UK & 881,963 & $26.2 \%$ \\
France & 729,340 & $21.6 \%$ \\
Netherlands & 397,709 & $11.8 \%$ \\
Denmark and Norway & 386,020 & $11.4 \%$ \\
Italy, Trieste and Ragusa & 352,713 & $10.5 \%$ \\
Hamburg, Bremen, Lubeck, Rostock, Dantzig and Prussia & 181,308 & $5.4 \%$ \\
Sweden & 169,279 & $5.0 \%$ \\
Spain & 149,460 & $4.4 \%$ \\
Portugal & 84,843 & $2.5 \%$ \\
Russia & 39,394 & $1.2 \%$ \\
Total & $3,372,09$ & $100 \%$ \\
\hline
\end{tabular}

Source: Romano (1962) 
Table 4.3. Exports plus imports as share of GDP

\begin{tabular}{|c|c|c|c|c|c|c|c|c|c|c|}
\hline & c. 1655 & c. 1720 & 1755 & c. 1790 & 1820 & 1830 & 1840 & 1850 & 1860 & 1870 \\
\hline Austria & & & & & & $11.4 \%$ & $14.2 \%$ & $13.2 \%$ & $18.7 \%$ & $29.0 \%$ \\
\hline Belgium & & & & & & & $19.0 \%$ & $26.7 \%$ & $31.3 \%$ & $35.6 \%$ \\
\hline Denmark & & & & & $7.5 \%$ & $17.5 \%$ & $27.5 \%$ & $36.5 \%$ & $29.7 \%$ & $35.7 \%$ \\
\hline Finland & & & & & & & & & $20.7 \%$ & $31.7 \%$ \\
\hline France & & $5.5 \%$ & $14 \%$ & $20 \%$ & $9.8 \%$ & $8.2 \%$ & $10.7 \%$ & $13.0 \%$ & $20.2 \%$ & $23.6 \%$ \\
\hline Germany & & & & & & & & $19.2 \%$ & $23.2 \%$ & $36.8 \%$ \\
\hline Greece & & & & & & & & & $42.7 \%$ & $45.6 \%$ \\
\hline Hungary & & & & & & & & & & $19.4 \%$ \\
\hline Italy & & & & & & & & & $16.1 \%$ & $18.3 \%$ \\
\hline Netherlands & $85 \%$ & $82 \%$ & $84 \%$ & $110 \%$ & $33.0 \%$ & $25.8 \%$ & $53.4 \%$ & $64.0 \%$ & $96.4 \%$ & $115.4 \%$ \\
\hline Norway & & & & & & & & & & $33.9 \%$ \\
\hline Portugal & & & & & & & & $42.4 \%$ & $33.9 \%$ & $33.7 \%$ \\
\hline Spain & & & & $15.7 \%$ & & $6.0 \%$ & & $7.3 \%$ & $11.2 \%$ & $11.7 \%$ \\
\hline Sweden & & & & & & $5.7 \%$ & $6.8 \%$ & $13.8 \%$ & $20.0 \%$ & $29.4 \%$ \\
\hline UK & & $19 \%$ & $20 \%$ & $24 \%$ & $21.4 \%$ & $18.8 \%$ & $25.2 \%$ & $27.8 \%$ & $41.8 \%$ & $43.6 \%$ \\
\hline $\begin{array}{l}\text { Best guess at total European trade } \\
\text { to GDP ratio }\end{array}$ & & & & & $13.4 \%$ & $11.4 \%$ & $15.4 \%$ & $18.0 \%$ & $24.9 \%$ & $29.9 \%$ \\
\hline Idem, net of intra-European trade & & & & & & $3.8 \%$ & & $6.3 \%$ & $8.9 \%$ & $9.2 \%$ \\
\hline
\end{tabular}

Notes: Ottoman Empire, Albania, Bulgaria, Rumania and Serbia are not included in total Europe. "UK" pre-1800 is just England and Wales.

Sources: Post-1800: Bairoch (1976), and data underlying Prados de la Escosura (2000). Pre-1800: Deane and Cole (1962 (1969)), Davis (1969, 1979), Officer (2001), Crafts (1985), Maddison (2001), de Vries and van der Woude (1997), McCusker (1978), Arnould (1791), Daudin (2005), Marczewski (1961), Prados de la Escosura (1993). 
Table 4.4. Entrepôt and special trade (£ million)

\begin{tabular}{|c|c|c|c|c|c|}
\hline & $\begin{array}{l}\text { Retained imports }(1)=\text { total } \\
\text { imports }- \text { Re-exports }\end{array}$ & $\begin{array}{l}\text { Domestic exports } \\
\text { (2) }\end{array}$ & Re-exports (3) & $\begin{array}{l}\text { Special trade (4) } \\
=(1)+(2)\end{array}$ & $\begin{array}{l}\text { Special trade as a } \\
\text { share of total trade } \\
= \\
100 *(4) /[(4)+(3)+(3)]\end{array}$ \\
\hline Britain (1784/86) & 19.2 & 13.6 & 3.6 & 32.8 & $82 \%$ \\
\hline France (1787) & 18.1 & 15.0 & 6.4 & 33.1 & $72 \%$ \\
\hline $\begin{array}{l}\text { Netherlands (using } 1770 \text { trade } \\
\text { composition) }\end{array}$ & 6.7 & 9.0 & 6.2 & 15.7 & $43 \%$ \\
\hline Spain (1788/92) & 6.4 & 5.4 & 3.6 & 11.8 & $62 \%$ \\
\hline Portugal (1796/1800) & 2.0 & 2.7 & 5.3 & 4.7 & $31 \%$ \\
\hline
\end{tabular}

Note: retained imports are computed assuming that the value of a good is recorded identically when it is imported and when it is re-exported. Special trade excludes both re-exports and non-retained imports.

Source: see Tables 4.1, 4.3.

Table 4.5. European real trade 1820-1870

\begin{tabular}{lcc}
\hline & $\begin{array}{c}1820 \\
\text { (million 1990 \$) }\end{array}$ & Growth 1820-1870 \\
\hline Austria & 47 & $+894 \%$ \\
Belgium & 92 & $+1,245 \%$ \\
France & 487 & $+621 \%$ \\
Italy & 339 & $+427 \%$ \\
Spain & 137 & $+550 \%$ \\
Switzerland & 147 & $+653 \%$ \\
UK & 1,125 & $+988 \%$ \\
Weighted average & & $+793 \%$ \\
US & 251 & $+12,010 \%$ \\
\hline
\end{tabular}

Source: Maddison (2001). 
Table 4.6. Composition of European overseas imports, 1513-1780

\begin{tabular}{|c|c|c|c|c|c|c|}
\hline \multicolumn{7}{|c|}{ Panel A. Imports from Asia to Lisbon, $1513-1610$ (\% by weight) } \\
\hline & 1513-19 & 1523-31 & $1547-8$ & $1587-8$ & $1600-3$ & 1608-10 \\
\hline Pepper & 80.0 & 84.0 & 89.0 & 68.0 & 65 & 69.0 \\
\hline Other spices & 18.4 & 15.6 & 9.6 & 11.6 & 16.2 & 10.9 \\
\hline Indigo & 0.0 & 0.0 & 0.0 & 8.4 & 4.4 & 7.7 \\
\hline Textiles & 0.2 & 0.0 & 0.0 & 10.5 & 12.2 & 7.8 \\
\hline Misc. & 1.4 & 0.4 & 1.4 & 1.5 & 2.2 & 4.6 \\
\hline Total & 100.0 & 100.0 & 100.0 & 100.0 & 100.0 & 100 \\
\hline \multicolumn{7}{|c|}{ Panel B. Imports of VOC into Europe, $1619-1780$ (\% by invoice value) } \\
\hline & 1619-21 & $1648-50$ & $1668-70$ & $1698-1700$ & $1738-40$ & 1778-80 \\
\hline Pepper & 56.5 & 50.4 & 30.5 & 11.2 & 8.1 & 9 \\
\hline Other spices & 17.6 & 17.9 & 12.1 & 11.7 & 6.1 & 3.1 \\
\hline Textiles & 16.1 & 14.2 & 36.5 & 54.7 & 41.1 & 49.5 \\
\hline Tea and coffee & & & & 4.2 & 32.2 & 27.2 \\
\hline Drugs, perfumes and dye-stuffs & 9.8 & 8.5 & 5.8 & 8.3 & 2.8 & 1.8 \\
\hline Sugar & & 6.4 & 4.2 & 0.2 & 3.7 & 0.6 \\
\hline Saltpetre & & 2.1 & 5.1 & 3.9 & 2.6 & 4.4 \\
\hline Metals & 0.1 & 0.5 & 5.7 & 5.3 & 1.1 & 2.7 \\
\hline Misc. & & 0.2 & 0.1 & 0.4 & 2.3 & 1.7 \\
\hline Total & 100.0 & 100.0 & 100.0 & 100.0 & 100.0 & 100 \\
\hline \multicolumn{7}{|c|}{$\begin{array}{c}\text { Panel C. Imports of English East India Company into Europe, 1668-1760 (\% of invoice value) } \\
\end{array}$} \\
\hline & 1668-70 & $1698-1700$ & 1738-40 & $1758-60$ & & \\
\hline Pepper & 25.25 & 7.02 & 3.37 & 4.37 & & \\
\hline Textiles & 56.61 & 73.98 & 69.58 & 53.51 & & \\
\hline Raw silk & 0.6 & 7.09 & 10.89 & 12.27 & & \\
\hline Tea & 0.03 & 1.13 & 10.22 & 25.23 & & \\
\hline Coffee & 0.44 & 1.93 & 2.65 & & & \\
\hline Indigo & 4.25 & 2.82 & & & & \\
\hline Saltpetre & 7.67 & 1.51 & 1.85 & 2.97 & & \\
\hline Misc. & 5.15 & 4.52 & 1.44 & 1.65 & & \\
\hline Total & 100 & 100 & 100 & 100 & & \\
\hline \multicolumn{7}{|c|}{ Panel D. Estimated annual sales of colonial imports, England and Netherlands, 1751-4 } \\
\hline & \multirow{2}{*}{\multicolumn{2}{|c|}{ Total sales (1000 pesos) }} & \multicolumn{4}{|c|}{ Percentage of sales } \\
\hline & & & \multicolumn{2}{|c|}{ From Asia } & \multicolumn{2}{|c|}{ Of total } \\
\hline Textiles & \multicolumn{2}{|c|}{6750} & \multicolumn{2}{|c|}{41.7} & \multicolumn{2}{|c|}{21.1} \\
\hline Pepper & \multicolumn{2}{|c|}{1100} & \multicolumn{2}{|c|}{6.8} & \multicolumn{2}{|c|}{3.4} \\
\hline Tea & \multicolumn{2}{|c|}{2800} & \multicolumn{2}{|c|}{17.3} & \multicolumn{2}{|c|}{8.7} \\
\hline Coffee & \multicolumn{2}{|c|}{1000} & \multicolumn{2}{|c|}{6.2} & \multicolumn{2}{|c|}{3.1} \\
\hline Spices & \multicolumn{2}{|c|}{1850} & \multicolumn{2}{|c|}{11.4} & & \\
\hline Misc. & & & & 6.7 & & \\
\hline Total from Asia & & & & 0.0 & & \\
\hline & & & From & America & & otal \\
\hline Sugar & & & & 0.8 & & \\
\hline Tobacco & & & & 3.3 & & \\
\hline Misc. & & & & 5.9 & & \\
\hline Total from America & & & & 0.0 & & \\
\hline Total overseas imports & & & & & & \\
\hline
\end{tabular}

Source: Findlay and O’Rourke (2007, pp. 308-9). 


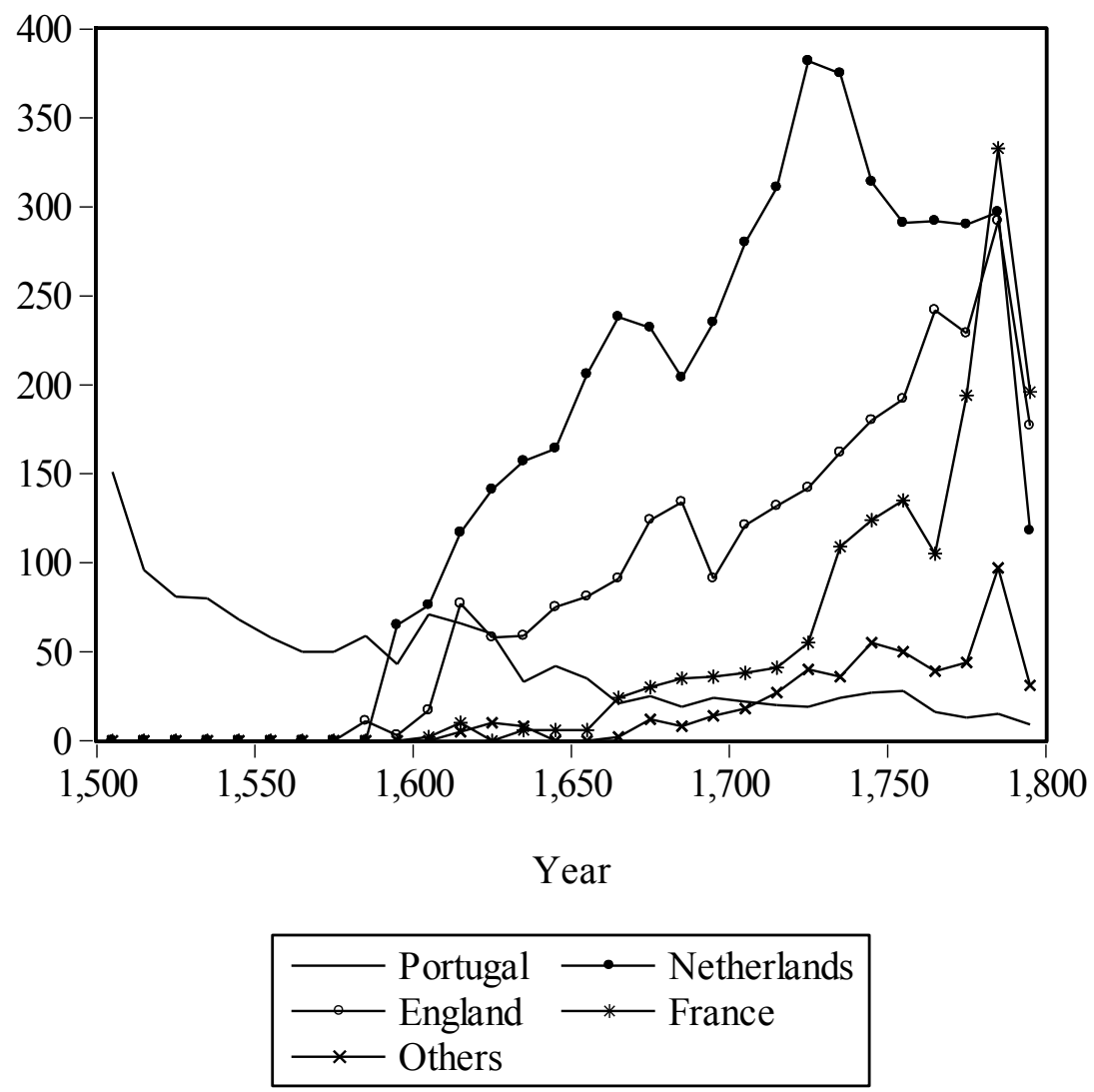

Figure 4.1. Numbers of ships sailing to Asia, per decade

Source: de Vries (2003). 


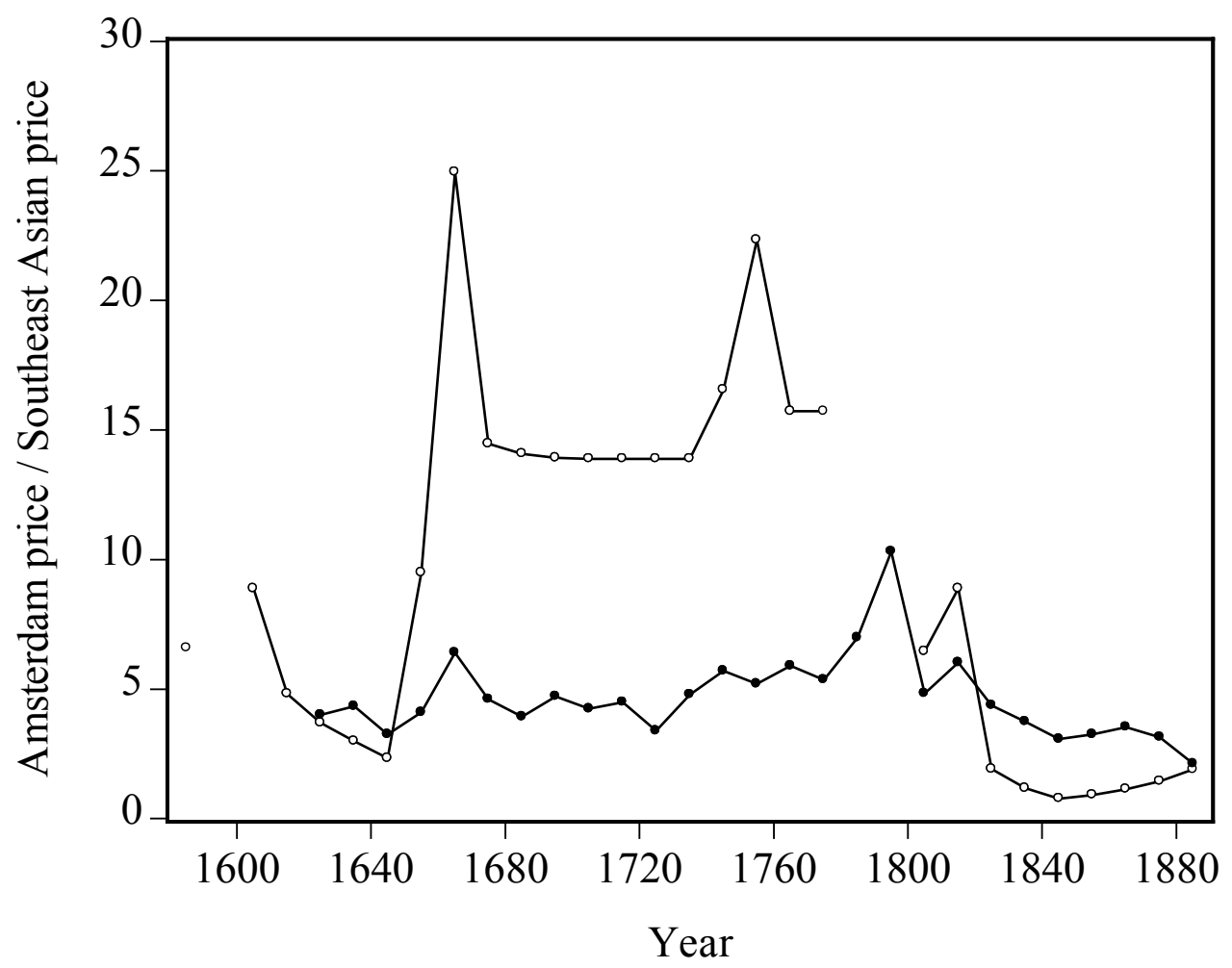

$\multimap$ Cloves $\longrightarrow$ Pepper

Figure 4.2. Spice markups, 1580-1890

(Amsterdam price / Southeast Asian price)

Source: Bulbeck et al. (1998). 


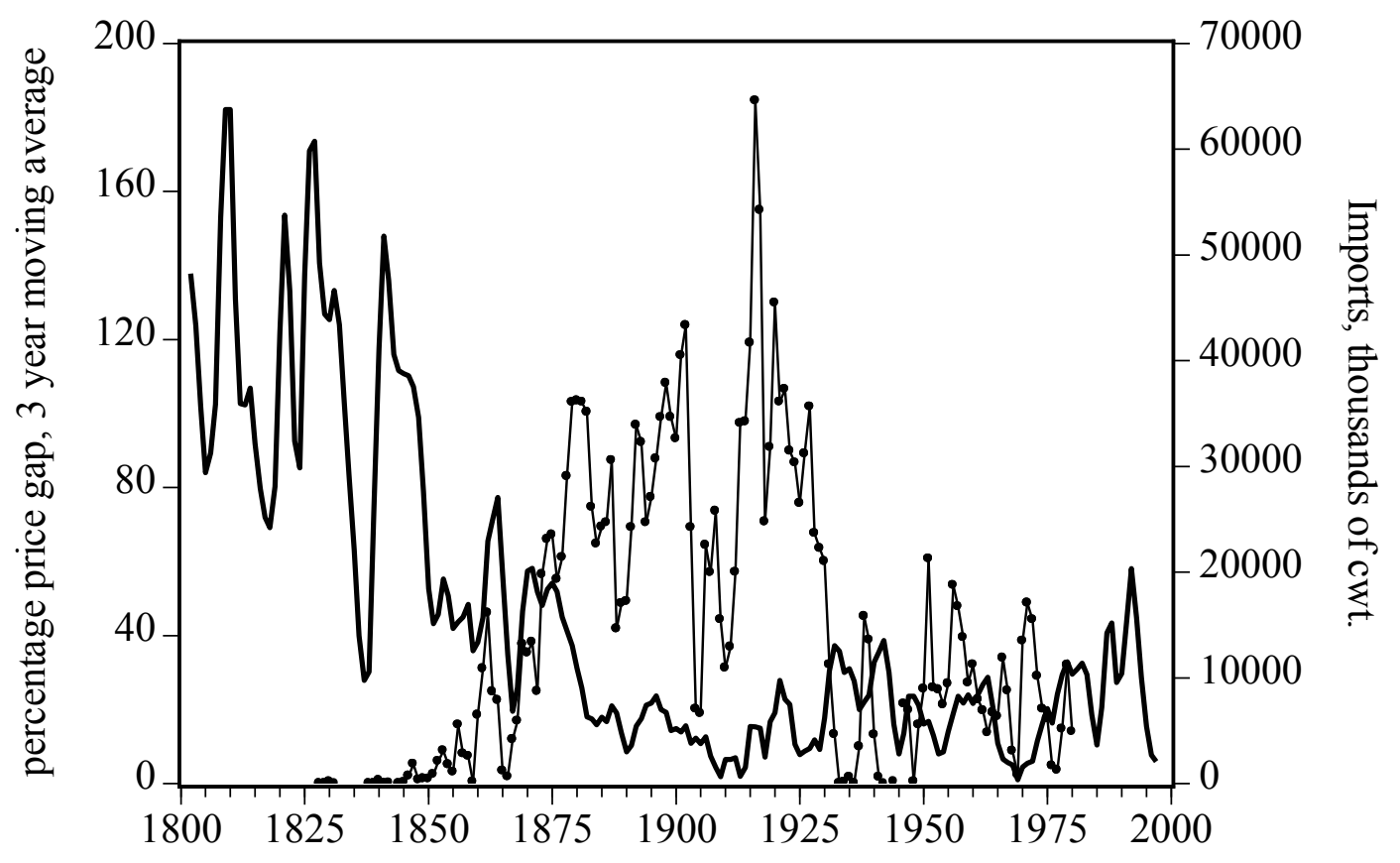

- Anglo-American wheat price gap British imports of US wheat

Figure 4.3. Anglo-American wheat trade, 1800-2000

Source: O'Rourke and Williamson (2005), p. 10. 


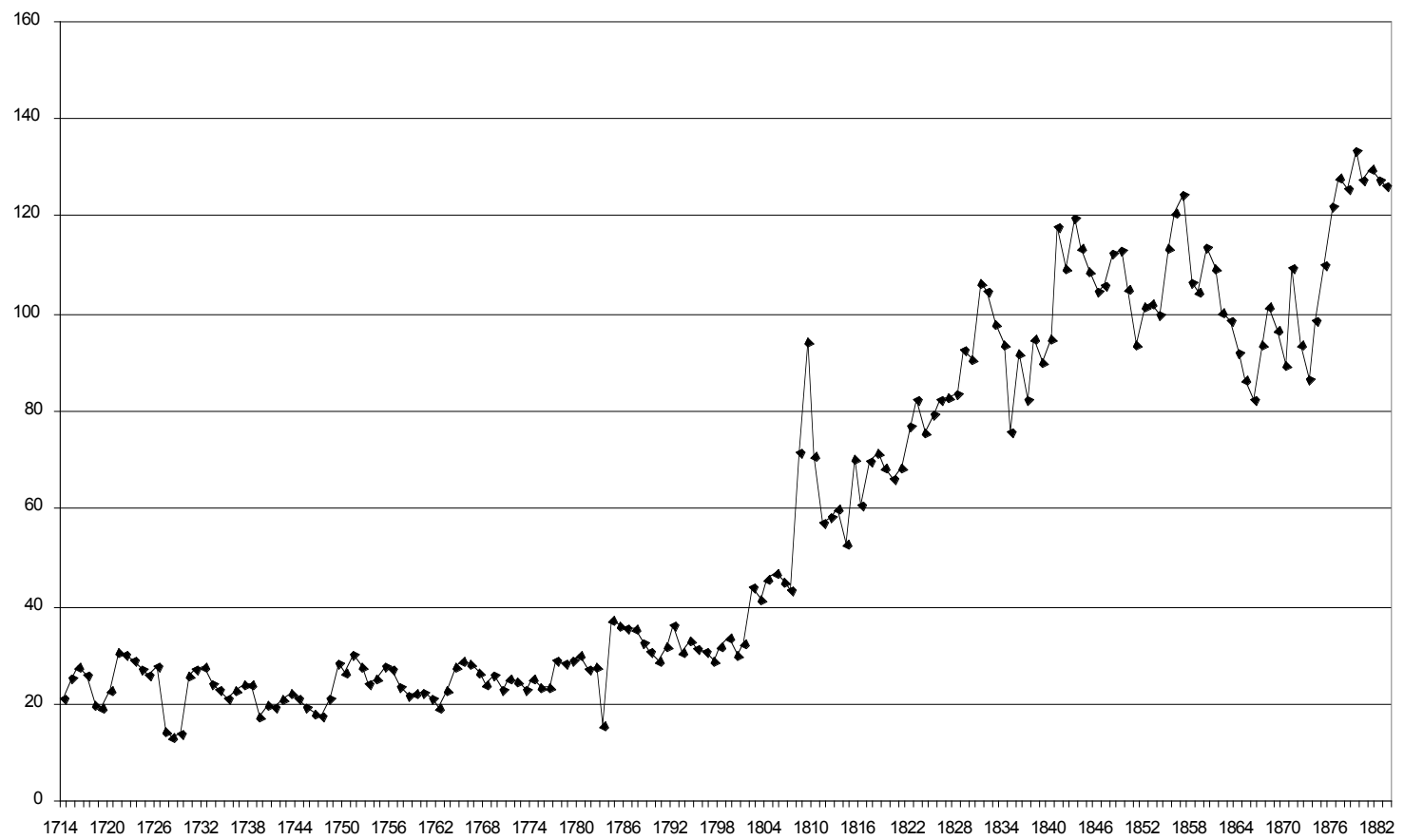

Figure 4.4. Spanish terms of trade vis-à-vis Britain 1714-1882 (1854=100)

Source: Prados de la Escosura (mimeo). 


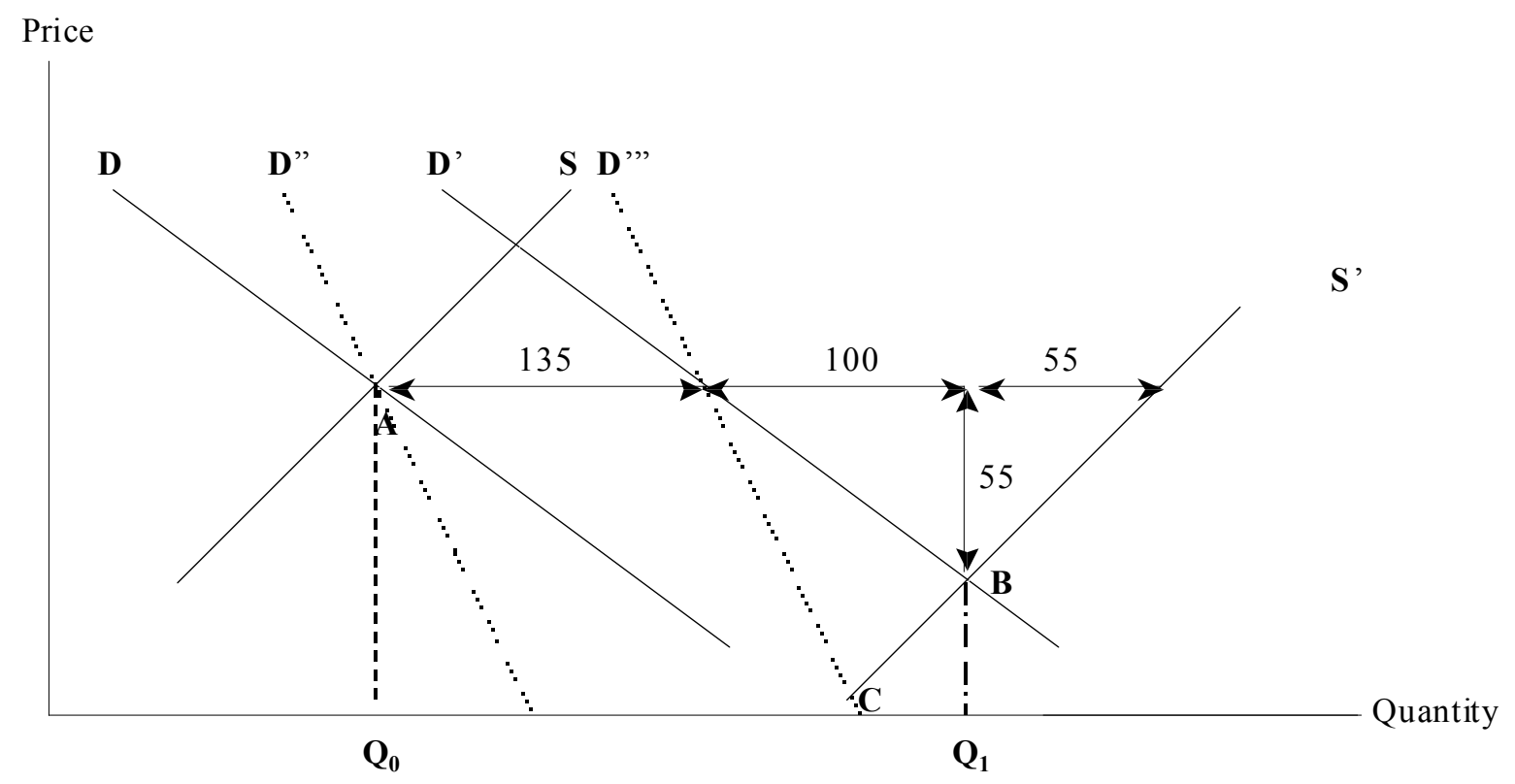

Figure 4.5. Demand versus supply during the Industrial Revolution

Source: Findlay and O'Rourke (2007), p. 306. 